\title{
PENGARUH PROFITABILITAS, PERTUMBUHAN PERUSAHAAN DAN LIKUIDITAS TERHADAP NILAI PERUSAHAAN
}

\author{
Candra Kurnia Saputri, Axel Giovanni \\ candrakurnias@outlook.com ${ }^{1}$, axelgiovanni@untidar.ac.id ${ }^{2}$ \\ Universitas Tidar
}

\begin{abstract}
ABSTRAK
Tujuan dari penelitian ini adalah untuk mengetahui pengaruh antara profitabilitas, pertunbuhan perusahaan dan likuiditas terhadap nilai perusahaan pada perusahaan sektor industri barang konsumsi yang terdaftar di Bursa Efek Indonesia pada tahun 2014 hingga tahun 2018. Penelitian ini dibuat karena masih adanya perbedaan hasil penelitian antara yang satu dengan lainnya serta adanya fluktuasi nilai perusahaan pada perusahaan sektor industri barang konsumsi yang terdaftar di Bursa Efek Indonesia. Populasi pada penelitian ini adalah perusahaan barang konsumsi yang terdaftar di Bursa Efek Indonesia pada tahun 2014-2018. Sedangkan sampel pada penelitian ini 37 perusahaan pada sektor industri barang konsumsi yang dipilih menggunakan metode purposive sampling. Teknik analisis data yang digunakan adalah analisis regresi berganda dengan tujuan untuk mengetahui hubungan antar variabel. Hasil dari penelitian ini menunjukkan bahwa profitabilitas, pertumbuhan perusahaan dan likuiditas secara simultan berpengaruh terhadap nilai berusahaan. Secara parsial profitabilitas berpengaruh positif dan signifikan terhadap nilai perusahaan, pertumbuhan perusahaan tidak berpengaruh terhadap nilai perusahaan dan likuiditas berpengaruh negatif dan signifikan terhadap nilai perusahaan.
\end{abstract}

Kata Kunci: Nilai Perusahaan, Profitabilitas, Pertumbuhan Perusahaan, Likuiditas.

\section{ABSTRACT}

The purpose of this study is to determine the effect of profitability, company growth and liquidity on the value of the company in the consumer goods industry sector companies listed on the Indonesia Stock Exchange in 2014 to year 2018. This research was made because there are still differences in research results between one another and the fluctuations in the value of companies in the consumer goods industry sector companies listed on the Indonesia Stock Exchange. The population in this study are consumer goods companies listed on the Indonesia Stock Exchange in 2014 - 2018. While the sample in this study 37 companies in the consumer goods industry sector were selected using the purposive sampling method. Data analysis technique used is multiple regression analysis with the aim to determine the relationship between variables. The results of this study indicate that profitability, company growth and liquidity simultaneously influence the value of the company. Partially, profitability has a positive and significant effect on firm value, company growth has no effect on firm value and liquidity has a negative and significant effect on firm value.

Keywords: Company Value, Profitability, Company Growth, Liquidity. 


\section{PENDAHULUAN}

\section{Latar Belankang}

Tujuan utama dari keputusan keuangan adalah menciptakan nilai bagi para investor (Brigham \& Houston, 2018). Nilai bagi para investor tercemin dari harga saham perusahaan yang juga mengagambarkan nilai dari sebuah perusahaan. Nilai perusahaan adalah harga yang akan dibayarkan oleh pembeli jika suatu perusahaan akan dijual (Dewi \& Candradewi, 2018). Ketika perusahaan telah memutuskan untuk menawarkan sahamnya ke publik maka nilai perusahaan diartikan sebagai pandangan seorang investor terhadap perusahaan tersebut. Investor dapat menggunakan nilai perusahaan sebagai dasar untuk melihat kinerja perusahaan pada periode mendatang, dimana nilai perusahaan dikaitkan dengan harga saham. Investor akan memperoleh keuntungan apabila harga saham tinggi (Suwardika \& Mustanda, 2017). Nilai perusahaan dianggap penting karena nilai perusahaan mencerminkan kinerja dari perusahaan yang mampu mempengaruhi presepsi investor terhadap perusahaan (Parta \& Sedana, 2018). Nilai perusahaan yang tinggi akan meningkatkan rasa percaya seorang investor terhadap perusahaan (Suwardika \& Mustanda, 2017)

Nilai perusahaan merupakan nilai sekarang dari arus pendapatan atau kas yang diharapkan diterima pada masa yang akan datang (Sudana, 2011). Menurut (Thomas, 2011) nilai perusahaan merupakan harga yang bersedia dibayarkan oleh pembeli apabila suatu perusahaan akan dijual. Tidak jauh berbeda dengan penelitian yang dilakukan oleh Husnan \& Pudjiastuti (2015) Nilai perusahaan merupakan harga yang bersedia dibayar oleh calon pembeli apabila perusahaan tersebut dijual, semakin tinggi nilai perusahaan, semakin besar kemakmuran yang akan diterima oleh pemilik perusahaan. (Yunita \& Artini, 2019) menyatakan bahwa nilai perusahaan adalah indikator yang penting dalam menilai kinerja suatu perusahaan, besar kecilnya nilai perusahaan dapat mempengaruhi investor dalam melakukan investasinya. Sedangkan (Noviani et al., 2019) menjelaskan bahwa nilai perusahaan dapat tercermin dari harga saham, semakin tinggi harga saham maka semakin tinggi tingkat pengembalian investor dan semakin tinggi nilai perusahaan tersebut.

Nilai perusahaan juga dapat mencerminkan kemakmuran pemegang saham, semakin tinggi nilai perusahaan akan berdampak pada semakin meningkat pula kemakmuran pemegang sahamnya, begitupun sebaliknya. Untuk dapat meningkatkan 
nilai perusahaan manjemen perusahaan akan menerapkan tata kelola perusahaan yang baik serta mempublikasikan informasi yang dapat meningkatkan nilai perusahaan (Parta \& Sedana, 2018).

Menurut Brigham \& Houston (2018) Ada beberapa variabel yang mempengaruhi nilai perusahaan diantaranya tanggung jawab yang terbatas mengurangi risiko, pertumbuhan perusahaan, likuiditas, profitabilitas dan struktur modal. Hal ini sesuai dengan penelitian yang dilakukan oleh Dewi \& Candradewi (2018) yang menyatakan bahwa profitabilitas dan struktur modal berpengaruh positif signifikan terhadap nilai perusahaan. Hal yang sama juga ditunjukkan pada penelitian Parta \& Sedana (2018) yang menyatakan adanya hubungan positif signifikan antara pertumbuhan perusahaan dan struktur modal terhadap nilai perusahaan. Dan penelitian yang dilakukan oleh Cahyani \& Wirawati (2019) yang menyatakan adanya hubungan positif signifikan antara profitabilitas dan likuiditas terhadap nilai perusahaan.

Salah satu variabel yang mempengaruhi nilai perusahaan adalah variabel profitabilitas. Profitabilitas merupakan sebuah gambaran bagaimana suatu perusahaan dapat menghasilkan keuntungan dari asset ataupun modal yang mereka miliki (Arifianto \& Chabachid, 2016). Profitabilitas yang tinggi menggambarkan bahwa perusahaan dapat menghasilkan keuntungan yang tinggi pula. Tingginya rasio profitabilitas tentunya akan menjadi daya tarik tersendiri bagi seorang investor yang ingin menginvestasikan uangnya pada suatu perusahaan. Semakin tinggi minat para investor untuk berinvestasi pada perusahaan tentunya akan meningkatkan harga saham perusahaan yang pada akhirnya meningkatkan nilai perusahaan. Profitabilitas juga mampu menggambarkan kinerja dari sebuah perusahaan. Hasil penelitian yang dilakukan (D. Dewi \& Sudiartha, 2017) menunjukkan bahwa profitabilitas berpengaruh positif signifikan terhadap nilai perusahaan. Penelitian yang dilakukan Dewi and Candradewi (2018) juga menyatakan bahwa profitabilitas berpengaruh positif signifikan terhadap struktur modal. Selaras dengan penelitian yang dilakukan oleh Arindita, G., Sampurno (2015) dan Kurniawan \& Mawardi (2017) yang menjelaskan bahwa variabel profitabilitas berpengaruh positif dan signifikan terhadap nilai perusahaan. Penelitian yang dilakukan Juhandi et al. (2013) menjelaskan bahwa profitabilitas berpengaruh negatif signifikan terhadap nilai perusahaan. Hal itu sesuai dengan penelitian yang dilakukan oleh (Herawati, 2011) yang menyatakan bahwa profitabilitas berpengaruh 
negatif dan signifikan terhadap nilai perusahaan. Disisi lain penelitian yang dilakukan oleh Anzlina dan Rustam (2013) menjelaskan bahwa profitabilitas tidak berpengaruh pada nilai perusahaan.

(Rajagukguk et al. (2019) menyatakan bahwa profitabilitas adalah kemampuan perusahaan untuk menghasilkan keuntungan atau laba. Kinerja suatu perusahaan dapat dinilai dari kemampuan perusahaan dalam menghasilkan laba, karena pada perusahaan profitabilitas dijadikan sebagai penilaian keefektifitasan pengelolaannya. Profitabilitas pada perusahaan dapat dinilai dengan bermacam cara tergantung pada laba dari aktiva atau modal yang diperbandingkan satu dengan lainnya. Profitabilitas merupakan indikator kinerja manajemen yang ditunjukkan melalui perolehan laba selama mengelola kekayaan perusahaan. Semakin besar jumlah profitabilitas perusahaan yang tercatat pada laporan keuangan dapat diartikan bahwa kinerja perusahaan tersebut baik, maka peluang perusahaan pada masa yang akan datang semakin baik (Noviani et al., 2019).

Variabel lain yang mempengaruhi nilai perusahaan adalah variabel pertumbuhan perusahaan. Pertumbuhan perusahaan adalah suatu rasio yang memperlihatkan kemampuan perusahaan untuk menjaga posisi ekonominya ditengah pertumbuhan perekonomian dan sektor usahanya (Suwardika \& Mustanda, 2017). Pertumbuhan perusahaan dapat menggambarkan apakah suatu perusahaan akan mengalami berkembangan atau tidak. Prtumbuhan perusahaan dapat diukur menggunakan Total Asset Growth (TAG). TAG adalah selisih total aktiva pada masa sekarang dengan masa sebelumnya terhadap total aktiva pada masa sebelumnya (Dewi \& Sudhiarta, 2017) Pertumbuhan perusahaan yang tinggi akan melambangkan perkembangan perusahaan yang baik secara internal maupun eksternal (Dewi \& Sudhiarta, 2017). Hasil penelitian yang dilakukan oleh (Parta \& Sedana, 2018) menjelaskan bahwa pertumbuhan perusahaan berpengaruh positif signifikan terhadap nilai perusahaan. Hal tersebut sejalan dengan penelitian yang dilakuakn oleh Hasbi (2015) yang menyatakan bahwa pertumbuhan perusahaan berpengaruh positif dan signifikan terhadap nilai perusahaan. Hal yang berbeda ditunjukkan pada penelitian yang dilakukan oleh Suwardika \& Mustanda (2017) yang menjelaskan bahwa variabel pertumbuhan perusahaan berpengaruh negatif signifikan terhadap nilai perusahaan. Penelitian dari Dewi \& Sudhiarta (2017) juga menyatakan bahwa variabel pertumbuhan perusahaan 
berpengaruh negatif signifikan terhadap nilai perusahaan. Disisi lain penelitian yang dilakukan oleh Dewi \& Candradewi (2018) menjelaskan hal yang berbeda yaitu variabel pertumbuhan perusahaan tidak memiliki pengaruh pada nilai perusahaan.

Dalam penelitian yang dilakukan oleh Noviani et al (2019) menjelaskan bahwa pertumbuhan perusahaan dapat dilihat berdasarkan penilaian yang tinggi dari pihak ekternal perusahaan terhadap aset yang dimiliki perusahaan maupun pertumbuhan pasar saham. Hal itu sejalan dengan penelitian yang dilakukan oleh Yunita \& Artini (2019) yang menjelaskan bahwa pertumbuhan perusahaan dapat dinyatakan dengan perubahan (peningkatan atau penurunan) total aset masa ini dibandingkan dengan total aset masa lalu. Perusahaan mengharapkan adanya pertumbuhan perusahaan karena semakin baik pertumbuhan perusahaan maka akan memberikan dampak baik terhadap perkembangan perusahaan.

Selain profitabilitas dan pertumbuhan perusahaan variabel yang mempengaruhi nilai perusahaan adalah likuiditas. Rasio likuiditas adalah salah satu rasio untuk mengukur kinerja perusahaan (Cahyani dan Wirawati, 2019). Rasio likuiditas mencerminkan kemampuan perusahaan dalam melunasi kewajiban jangka pendeknya atau seberapa cepat perusahaan mengubah aset yang dimilikinya menjadi kas (Sukamulja, 2019) Rasio likuiditas penting bagi suatu perusahaan karena rasio ini dapat menggambarkan risiko kredit jangka pendek dan efisiensi penggunaan aset jangka pendek perusahaan. Semakin tinggi tingkat likuiditas suatu perusahaan maka semakin tinggi pula tingkat kemampuan perusahaan dalam memenuhi kewajiban jangka pendeknya dengan baik. Manajer suatu perusahaan perlu menjaga tingkat likuiditas karena apabila likuiditas baik maka perusahaan akan efektif dalam menghasilkan laba yang nantinya akan berdampak pada nilai perusahaan. Perusahaan dikatakan likuid apabila suatu perusahaan memiliki dana lancar yang lebih besar dari pada utang lancarnya sehingga dapat menandakan bahwa perusahaan tersebut dalam keadaan sehat yang nantinya juga dapat meningkatkan kredibilitas perusahaan dimata para investor. Penelitian yang dilakukan oleh Cahyani dan Wirawati (2019) mengatakan bahwa likuiditas berpengaruh positif signifikan terhadap nilai perusahaan. Hal tersebut sejalan dengan penelitian yang dilakukan oleh Sukarya \& Baskara (2019), dan Uttari \& Yadnya (2018) yang juga menyatakan bahwa likuiditas berpengaruh positif signifikan terhadap nilai perusahaan. Berbeda dengan penelitian yang dilakukan oleh Astuti \& Yadnya 
(2019) yang menjelaskan bahwa likuiditas berpengaruh negatif signifikan terhadap nilai perusahaan. Hasil yang sama juga ditunjukkan pada penelitian yang dilakukan oleh Permana \& Rahyuda (2018) yang menyatakan bahwa likuiditas berpengaruh negatif signifikan terhadap nilai perusahaan.

Likuiditas merupakan kemampuan perusahaan untuk melunasi kewajiban finansialnya dalam jangka pendek dengan dana yang tersedia. Seperti membayar gaji, membayar biaya operasional, membayar utang jangka pendek dan yang lain yang membutuhkan pembayaran segera. Posisi dana lancar harus selalu lebih besar dari pada utang lancar, agar perusahaan dikatakan likuid yang menandakan perusahaan itu sehat (Cahyani dan Wirawati, 2019). Likuiditas suatu perusahaan dapat dilihat dari nilai current ratio $(\mathrm{CR})$ dan quick ratio $(\mathrm{QR})$. Nilai current ratio $(\mathrm{CR})$ dan quick ratio (QR)yang semakin tinggi menunjukkan perusahaan memiliki tingkat likuidasi yang baik sehingga dapat meningkatkan nilai perusahaan di mata investor serta memberikan persepsi yang positif terhadap kondisi perusahaan. Sedangkan Sukamulja (2019) menyatakan bahwa likuiditas dapat menunjukkan seberapa cepat perusahaan dapat megubah aset yang dimiliki menjadi kas.

Nilai perusahaan dianggap penting karena nilai perusahaan mencerminkan kinerja perusahaan yang akan mempengaruhi prespsi investor. Dalam memaksimalkan nilai perusahaan, manajemen perusahaan harus memperhatikan berbagai faktor yang dapat mempengaruhi nilai perusahaan seperti risiko yang dihadapi perusahaan, pertumbuhan perusahaan, profitabilitas, likuiditas, pertumbuhan ekonomi dan struktur modal. Seringkali perusahaan mengalami fluktuasi dalam nilai perusahaannya karena kondisi perekonomian yang tidak stabil dan kurang optimalnya struktur modal yang perusahaan tetapkan yang nantinya akan berpengaruh pada kinerja perusahaan. Berikut merupakan data fluktuasi nilai perusahaan barang konsumsi yang terdaftar pada Bursa Efek Indonesia pada tahun 2014 - 2016.

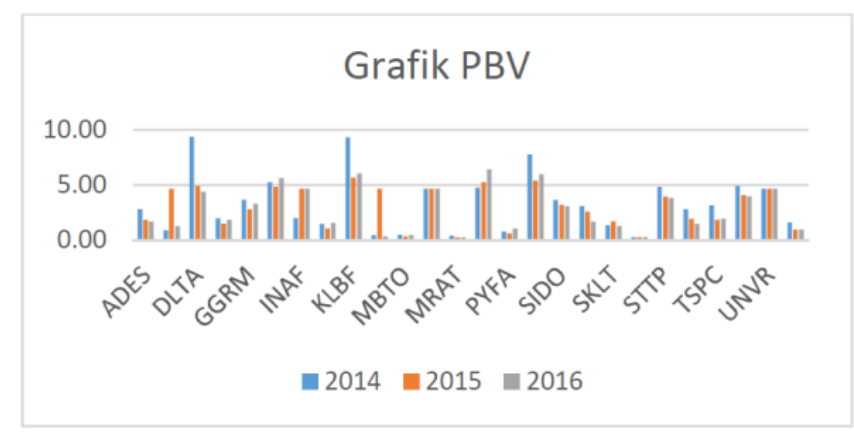


Apabila kinerja perusahaan terganggu maka pertumbuhan perusahaan akan berjalan lambat dan nantinya akan mempengaruhi presepsi investor terhadap perusahaan. Apabila presepsi investor terhadap perusahaan sudah negatif maka perusahaan akan kesulitan dalam mencari pendanaan eksternal perusahaan yang nantinya akan mempengaruhi kegiatan operasional perusahaan. Maka dari itu dalam memaksimalkan nilai perusahaan, manajemen perusahaan harus memperhatikan berbagai faktor yang dapat mempengaruhi naik turunnya nilai perusahaan. Berdasarkan uraian penelitian terdahulu yang telah dilakukan mengenai nilai perusahaan masih menghasilkan hasil yang belum konsisten sehingga penulis melakukan penelitian mengenai faktor - faktor yang mempengaruhi nilai perusahaan. Dalam penelitian ini faktor - faktor yang dipilih adalah profitabilitas dan pertumbuhan perusahaan sebagai variabel Independen. Selain itu adanya identifikasi masalah mengenai adanya fluktuasi nilai perusahaan juga menjadi salah satu pendorong penulis dalam melakukan penelitian ini.

Dengan adanya penelitian ini diharapkan dapat memberikan sumbangan pemikiran khusunya mengenai nilai perusahaan yang nantiya dapat memberikan tambahan pengetahuan, wawasan dan pengalaman baik bagi penulis maupun pembaca mengenai permasalahan yang sedang dikaji. Penelitian ini juga diharapkan dapat menjadi salah satu referensi untuk penelitian-penelitian selanjutnya khusunya yang berhubungan dengan niali perusahaan. Selain itu penelitian ini diharapkan mampu memberikan informasi kepada perusahaan terutama manajer keuangan tentang faktor faktor yang mempengaruhi nilai perusahaan serta memberikan gambaran bagi investor terkait keputusan investasi dengan mempertimbangkan nilai perusahaan yang bersangkutan.

\section{METODE}

\section{Desain Penelitian}

Desain penelitian yang digunakan dalam penelitian ini adalah penelitian Correlation Research yaitu penelitian yang dialakukan untuk melihat hubungan diantara dua variable. Korelasi tidak menjamin adanya kausaliti (hubungan sebab akibat), tetapi kausaliti menjamin adanya korelasi. Dimana Variabel dalam penelitian ini ada profitabilitas $\left(\mathrm{X}_{1}\right)$, pertumbuhan Perusahaan $\left(\mathrm{X}_{2}\right)$, dan Nilai Perusahaan $\left(\mathrm{Y}_{1}\right)$. Peneitian ini menggunakan pendekatan kuantitatif. 


\section{Subjek Penelitian}

Subjek penelitian yang digunakan pada penelitian ini adalah perusahaanperusahaan pada sektor industri barang konsumsi yang terdaftar di Bursa Efek Indonesia (BEI) pada periode 2014 sampai 2018

\section{Teknik Pengumpulan Data}

Jenis data yang dipakai dalam penelitian ini adalah data sekunder. Data sekunder adalah data yang mengacu pada informasi yang dikumpulkan dari sember sumber yang sudah ada (Sekaran \& Bougie, 2017). Dimana data diperoleh dari Bursa Efek Indonesia (BEI) dengan mengakses www.idx.co.id. Metode pengumpulan data dalam penelitian ini dilakukan melalui studi pstaka dengan membaca buku dan jurnal yang relevan untuk memperoleh landasan teori yang baik. Data sekunder dalam penelitian ini diperoleh dengan metode dokumentasi, yaitu dengan mengumpulkan data yang relevan dalam penelitian ini dari www.idx.co.id.

\section{Populasi dan Sampel}

Populasi dalam penelitian ini adalah seluruh perusahaan barang konsumsi yang terdafar di Bursa Efek Indonesia. Sampel dalam penelitian ini diambil menggunakan metode purposive sampling untuk mendapatkan sampel yang sesuai dengan karateristik yang telah ditentukan. Adapun karateristik sampel yang ditentukan adalah sebagai berikut :

1. Perusahaan barang konsumsi yang terdafar di Bursa Efek Indonesia pada tahun 2014-2018

2. Memiliki data yang lengkap terkait dengan variabel-variabel yang digunakan dalam penelitian ini yaitu nilai perusahaan, profitabilitas, pertumbuhan perusahaan dan likuiditas.

3. Perusahaan non-keuangan secara konsisten mempublikasikan laporan tahunan maupun laporan keuangan periode 2014-2018 secara berturut-turut baik di situs resmi milik perusahaan, situs resmi milik Bursa Efek Indonesia.

Berdasarkan kriteria diatas maka sampel yang digunakan dalam penelitian ini adalah 37 perusahaan pada sektor industri barang konsumsi yang terdaftar di Bursa Efek Indonesia pada periode 2014 hingga periode 2018. 


\section{Teknik Analisis Data}

Dalam penelitian ini teknik analisis data yang digunakan adalah analisis regresi berganda dengan tujuan untuk mengetahui hubungan antar variabel. Variabel yang digunakan dalam penelitian ini adalah variabel dependen dan variabel independen. Variabel dependen dalam penelitian ini adalah nilai perusahaan. Nilai perusahaan dalam penelitian ini diukur menggunakan Price Book Value (PVB). Price Book Value adalah perbandingan antara harga per lembar saham dengan nilai buku perusahaan. Price Book Value dapat diukur menggunakan rumus beriut :

$$
\text { Price Book Value }=\frac{\text { Harga Saham }}{\text { Nilai Buku }}
$$

Variabel Independen dalam penelitian ini adalah profitabilitas, pertumbuhan perusahaan dan likuiditas. Profitabilitas dalam penelitian ini diukur menggunakan Return on Equiy (ROE). Dalam penelitian ini pengukuran profitabilitas dilakukan dengan ROE karena ROE merupakan rasio pengukuran kemampuan perusahaan untuk menghasilkan laba dari ekuitas yang dimiliki perusahaan. Selain itu ROE juga dapat mencerminkan tingkat pengembalian dari saham yang dimiliki perusahaan untuk pemegang sahamnya sehingga lebih besar pengaruhnya pada nilai perusahaan bila dibandingkan dengan ROA yang mengukur tingkat pengembalian atas investasi perusahaan yg dalam hal ini dinilai melalui aset perusahaan (Sukamulja, 2019). ROE dapat diukur menggunakan rumus berikut :

$$
\text { Returon on Equity }=\frac{\text { Laba Bersih }}{\text { Total Ekuitas }}
$$

Variabel pertumbuhan perusahaan dalam penelitian ini diukur menggunakan Total Asset Growth (TAG). TAG merupakan perbandingan dari hasil pengurangan total aktiva yang dimiliki oleh perusahaan pada masa sekarang dengan masa sebelumnya terhadap total aktiva masa sebelumnya pada perusahaan tersebut (Dewi dan Candradewi, 2018). Berikut merupakan rumus perhitungan TAG :

$$
T A G=\frac{\text { Total Aset }_{t}-\text { Total Aset }_{t-1}}{\text { Total Aset }_{t-1}}
$$

Dan liabilitas dalam penelitian ini diukur menggunakan current ratio. Current ratio adalah perbandingan antara aset lancar perusahaan terhadap liabilitas jangka pendeknya. Berikut merupakan rumus perhitungan Current Ratio dalam penelitian ini :

$$
\text { Current Ratio }=\frac{\text { Aset Lancar }}{\text { Liabilitas Lancar }}
$$




\section{HASIL DAN PEMBAHASAN}

\section{Statistika Deskriptif Penelitian}

Analisa statistik deskriptif memperlihatkan jumlah data yang digunakan dalam penelitian, nilai minimum, nilai maksimum, mean (rata-rata), dan deviasi standar. Tabel statistika deskriptif dalam penelitian ini disajikan dalam tabel berikut :

Tabel 1

Statistik Deskriptik

\begin{tabular}{lrrrrr}
\hline \multicolumn{1}{c}{ Variabel } & $\mathrm{N}$ & \multicolumn{1}{c}{ Min } & \multicolumn{1}{c}{ Max } & \multicolumn{1}{c}{ Mean } & Standar Deviasi \\
\hline PBV & 185 & -2.92 & 82.44 & \multicolumn{1}{c}{5.7222} & 11.66261 \\
\hline ROE & 185 & -37.98 & 224.46 & 18.1058 & 34.28251 \\
\hline TAG & 185 & -79.18 & 621.88 & 14.3381 & 55.67760 \\
\hline Current Ratio & 185 & 15.24 & 1026.42 & 270.8056 & 191.08144 \\
\hline Valid N (listwise) & 185 & & & & \\
\hline
\end{tabular}

Sumber : Data diolah penulis menggunakan SPSS 24, 2020

Tabel 1 menunjukkan bahwa jumlah data yang digunakan dalam penelitian ini sebanyak 185 sampel. Dari hasil statistik deskriptif dapat dijelaskan bahwa variabel Nilai Perusahaan (PBV) memiliki nilai rata - rata sebesar 5,7222 dan memiliki standar deviasi sebesar 11,66261. Nilai minimum sebesar -2,92 dimiliki oleh Bentoel Internasional Investam pada tahun 2014 sedangkan nilai maksimum sebesar 82,44 dimiliki oleh Unilever Indonesia Tbk pada tahun 2017.

Variabel Profitabilitas (ROE) memiliki nilai rata - rata sebesar 18,1058 dan memiliki standar deviasi sebesar 34,28251. Nilai minimum sebesar -37,98 dimiliki oleh Martina Berto Tbk. pada tahun 2018 sedangkan nilai maksimum sebesar 224,46 dimiliki oleh Merck Tbk pada tahun 2018. Variabel Pertumbuhan Perusahaan (TAG) memiliki nilai rata-rata sebesar 14,3381 dan memiliki standar deviasi sebesar 55,67760. Nilai minimum sebesar -79,18 dimiliki oleh Tiga Pilar Sejahtera Food Tbk pada tahun 2018 sedangkan nilai maksimum sebesar 621,88 dimiliki oleh Bumi Teknokultura Unggul Tbk pada tahun 2015. Variabel Likuiditas (Current Ratio) memiliki nilai rata - rata sebesar 270,8056 dan memiliki standar deviasi sebesar 191,08144. Nilai minimum sebesar 15,24 dimiliki oleh Tiga Pilar Sejahtera Food Tbk pada tahun 2018 sedangkan nilai maksimum sebesar 1025,42 dimiliki oleh Industri Jamu dan Farmasi Sido pada tahun 2014.

\section{Uji Normalitas}

Dalam penelitian ini uji normalitas dilakukan dengan grafik normal p-plot regression standardize residual dan uji one-sample kolmogorov-smirnov test dengan 
$\alpha=5 \%$. Uji Normalitas dilakukan dengan tujuan untuk mengetahui apakah nilai residual dalam penelitian telah berdistribusi secara normal atau tidak (Ghazali, 2018). Hasil uji normalitas disajikan dalam tabel berikut:

Tabel 2

\begin{tabular}{llr}
\hline \multicolumn{3}{c}{ One Sample Kolmogorov-Smirnov Test } \\
\hline $\mathrm{N}$ & & Unstandardized Residual \\
\hline Normal Parameters & Mean & 185 \\
& Std. Deviation & .0000000 \\
& Absolute & 8.85217775 \\
\hline & Positive & .262 \\
& Negative & .262 \\
& & -.247 \\
\hline Test Statistic & & \\
\hline Asymp. Sig. (2-tailed) & & \\
\hline
\end{tabular}

Sumber : Data diolah penulis menggunakan SPSS 24, 2020

Tabel 2 diatas menunjukkan hasil uji normalitas menggunakan metode onesample kolmogorov-smirnov test, dimana nilai Asymp.Sig. (2-tailed) menunjukkan angka 0,000 yang mana lebih kecil dari nilai signifikansi sebesar 0,05. Nilai tersebut menunjukkan bahwa nilai residual dalam penelitian ini berdistribusi secara tidak normal. Namun Levine et al. (2017) menyatakan bahwa bahwa "However, for many analyses, you will either be able to know that the population is not normally distributed or conclude that it would be unrealistic to assume that the population is normally distributed then the central limit theorem deals with this situation". Central Limit Theorem menyatakan bahwa dalam konteks sampel penelitian yang besar dapat diasumsikan distribusi dari nilai rata-rata sampel adalah normal. Maksud dari penelitian yang besar disini adalah penelitian yang menggunakan jumlah sampel lebih dari 30 sampel. Central Limit Theorem digunakan dalam penelitian ini untuk mengakomodir masalah ketidaknormalan ditribusi residual dalam konteks penelitian ini.

\section{Uji Autokolerasi}

Uji Autokolerasi bertujuan untuk menguji apakah dalam model regresi linier ada kolerasi antara kesalahan pengganggu pada periode $t$ dengan kesalahan pengganggu pada periode t-1 (sebelumnya). Pada penelitian ini uji autokolerasi dilakukan dengan metode runt test. Hasil uji autokolerasi menggunakan uji runt tes diperoleh nilai Asymp. Sig. (2-tailed) sebesar 0.000. Nilai Asymp. Sig. (2-tailed) lebih kecil dari nilai signifikansi yang digunakan yaitu 5\%, hal itu menunjukkan bahwa terdapat masalah autokorelasi dalam model regresi penelitian. Hasil uji autokorelasi model regresi pada penelitian ini disajikan melalui tabel berikut : 
Tabel 3

Uji Autokorelasi

Run Test

\begin{tabular}{lr}
\hline & Unstandardized Residual \\
\hline Test Value & -.06738 \\
\hline Cases $<$ Test Value & 15 \\
\hline Cases $>=$ Test Value & 16 \\
\hline Total Cases & 60 \\
\hline Number of Runs & 15 \\
\hline$Z$ & .000 \\
\hline Asymp. Sig. (2-tailed) & 1.000 \\
\hline
\end{tabular}

Sumber : Data diolah penulis menggunakan SPSS 24, 2020

\section{Uji Heteroskedastisitas}

Uji Heteroskedastisitas dalam penelitian ini dilakukan menggunakan uji glejser. Hasil dari uji glejser diperoleh nilai signifikansi dari masing - masing variabel independen sebesar 0.000 untuk variabel ROE, 0.139 untuk variabel TAG dan 0,001 untuk variabel Current Asset. Nilai signifikansi dari variabel TAG lebih tinggi dari nilai signifikansi yang digunakan yaitu 5\%, hal itu menunjukkan bahwa pada variabel TAG tidak terdapat masalah heteroskedastisitas. Namun pada variabel ROE dan Current Ratio menunjukkan hasil yang lebih rendah dari nilai signifikansi yang digunakan yaitu $5 \%$, hal itu berarti menunjukkan adanya masalah heteroskedastisitas dalam model regresi penelitian ini. Hasil uji glejser disajikan dalam tabel berikut ini :

\section{Tabel 4}

Uji Heteroskedastisitas

Coefficients

\begin{tabular}{|c|c|c|c|c|c|c|}
\hline \multirow[b]{2}{*}{ Model } & & \multicolumn{2}{|c|}{$\begin{array}{c}\text { Unstandardized } \\
\text { Coefficients }\end{array}$} & \multicolumn{2}{|l|}{$\begin{array}{c}\text { Standardized } \\
\text { Coefficients }\end{array}$} & \multirow[b]{2}{*}{ Sig. } \\
\hline & & B & $\begin{array}{l}\text { Std. } \\
\text { Error }\end{array}$ & Beta & $\mathrm{t}$ & \\
\hline 1 & (constant) & 3.684 & .829 & & 4.444 & .000 \\
\hline & ROE & .137 & .013 & .606 & 10.828 & .000 \\
\hline & TAG & .012 & .008 & .083 & 1.485 & .139 \\
\hline & Current Ratio & -.007 & .002 & -.184 & -3.252 & .001 \\
\hline
\end{tabular}

Sumber : Data diolah penulis menggunakan SPSS 24, 2020

\section{Uji Multikoleniaritas}

Uji Multikoleniaritas dilakukan dengan tujuan untuk menguji apakah dalam model regresi ditemukan adanya korelasi antar variabel bebas (Ghozali, 2016). Model regresi yang baik seharusnya tidak terjadi korelasi diantara variabel bebas. Uji Multikoleniaritas dapat dilihat melalui nilai tolerance dan nilai variance inflation factor (VIF). Apabila nilai tolerance menunjukkan hasil lebih dari 0,10 (Tolerance $\geq 0,10)$ dan 
nilai VIF kurang dari 10 (VIF $\leq 10)$ maka dapat disimpulkan bahwa tidak terdapat multikoleniaraitas dalam variabel bebasnya. Hasil uji multikoleniaritas disajikan dalam teabel berikut ini:

Tabel 5

Uji Multikoleniaritas

\begin{tabular}{llllll}
\hline & & \multicolumn{4}{c}{ Collinearity Statistics } \\
\hline Model & & B & Tolerance & VIF \\
\hline 1 & (constant) & 3.765 & & & \\
\hline & ROE & .209 & .777 & 1.287 \\
\hline & TAG & .016 & .973 & 1.027 \\
\hline & Current Ratio & -.008 & .786 & 1.273 \\
\hline
\end{tabular}

Sumber : Data diolah penulis menggunakan SPSS 24, 2020

Hasil dari uji multikoleniaritas diperoleh nilai variance inflation factor (VIF) dari masing - masing variabel independen penelitian adalah sebesar 1.021, 1.016, 1.037. Nilai VIF dari masing-masing variabel independen tersebut kurang dari 10 yang artinya menunjukkan bahwa tidak terdapat masalah multikoleniaritas dalam model regresi penelitian ini. Begitu pula dengan nilai tolerance dari masing - masing variabel yang juga menunjukkan niali lebih dari 0.10 yaitu sebesar $0.980,0.984$, dan 0.964 yang juga berarti tidak terdapat masalah multikoleniaritas dalam model regresi penelitian ini.

\section{Robust Standard Error}

Hasil dari uji asumsi klasik menunjukkan bahwa terdapat masalah autokorelasi dan heteroskedastisitas dalam model regresi. (Gujarati \& Porter, 2015) menyatakan bahwa masalah autokorelasi dan heteroskedastisitas yang terdapat dalam model regresi menyebabkan inferensi secara statistik dalam penelitian ini menjadi tidak valid. Penelitian ini menggunakan prosedur robust standard error untuk menanggulangi masalah tersebut. Robust standard error merupakan prosedur valid dalam analisis regresi yang bertujuan untuk mengatasi keberadaan autokorelasi dan heteroskedastisitas dalam model (Gujarati \& Porter, 2009). Poin penting yang perlu diperhatikan terkait robust standard error adalah prosedur ini tidak menghilangkan keberadaan autokorelasi dan heteroskedastisitas dalam model regresi, prosedur ini berkerja dengan mengoreksi atau melakukan suatu adjustment terhadap standard error model regresi sehingga penarikan kesimpulan secara statistik tetap dapat dilakukan. Hasil final model regresi penelitian ini setelah dilakukan robust test disajikan dalam tabel berikut ini: 
Tabel 6

Model Regresi Penelitian

\begin{tabular}{ccccc}
\hline Variabel & $\begin{array}{c}\text { Koefisien } \\
\text { Regresi }\end{array}$ & $\begin{array}{c}\text { Robust Standard } \\
\text { Error }\end{array}$ & $\mathrm{t}$ & $\mathrm{P}$ \\
\hline (contstant) & 3.7655 & 1.4671 & 2.5665 & .0111 \\
\hline ROE & .2093 & .0778 & 2.6908 & .0078 \\
\hline TAG & .0157 & .0371 & .4221 & .6734 \\
\hline Current Ratio & -.0076 & .0026 & -2.8733 & .0045 \\
\hline
\end{tabular}

Sumber : Data diolah penulis menggunakan SPSS 24, 2020

\section{Koefisien Determinasi}

Koefisisen determinasi menunjukkan besarnya pengaruh variabel independen dalam penelitian yaitu profitabilitas, pertumbuhan perusahaan dan likuiditas terhadap nilai perusahaan pada perusahaan sektor industri barang konsumsi yang terdaftar di BEI pada periode 2014-2018. Berikut merupakan tabel koefisie determinasi dalam penelitian ini:

\section{Tabel 7}

Koefisien Determinasi

Model Regression Summary

\begin{tabular}{ccrlrlr}
\hline Model & $\mathrm{R}$ & R Square & $\begin{array}{l}\text { Adjusted } \\
\text { Square }\end{array}$ & $\mathrm{R}$ & $\begin{array}{l}\text { Std. Error } \\
\text { Estimate }\end{array}$ & of the \\
\hline 1 & .6511 & .4239 & .4143 & & 8.9252 \\
\hline
\end{tabular}

Sumber : Data diolah penulis menggunakan SPSS 24, 2020

Dari tabel diatas dapat kita lihat bahwa nilai koefisien determinasi yang dijelaskan oleh nilai Adjusted R Square menunjukkan nilai sebesar 0,4143 atau 41,43\%. Nilai koefisien determinasi tersebut menjelaskan bahwa 41,43 persen variasi nilai perusahaan dapat dijelaskan melalui profitabilitas perusahaan, pertumbuhan perusahaan dan tingkat likuiditas perusahaan. Sedangkan pengaruh faktor lain yang tidak diamati oleh peneliti adalah sebesar (100\%-41,43\%) 58,57\%, pengaruh tersebut merupakan pengaruh lain diluar variabel independen dalam penelitian.

\section{Uji F}

Hasil dari uji $\mathrm{F}$ diperoleh kesimpulan bahwa profitabilitas, pertumbuhan perusahaan dan likuiditas perusahaan terbukti secara bersama - sama atau simultan berpengaruh terhadap variabel nilai perusahaan. Hal itu dibuktikan dengan nilai $\mathrm{P}$ sebesar 0,0031 yang lebih kecil dari nilai signifikansi yang digunakan dalam penelitian yaitu 5\%. Hasil Uji Statistik F penelitian ini juga membuktikan bahwa model regresi peneltian ini terspesifikasi secara tepat. Hasil uji $\mathrm{F}$ dalam penelitian ini disajikan dalam tabel berikut ini: 


\section{Tabel 8}

Hasil Uji F

\begin{tabular}{|c|c|c|}
\hline $\mathbf{F}$ & $\mathbf{P}$ & Hasil \\
\hline 4.7825 & .0031 & Signifikan \\
\hline
\end{tabular}

\section{Uji t}

Sumber : Data diolah penulis menggunakan SPSS 24, 2020

Hasil uji t dalam penelitian ini menyatakan bahwa variabel profitabilitas dan likuiditas perusahaan berpengaruh secara parsial terhadap nilai perusahaan dengan nilai P yang diperoleh kurang dari nilai signifikansi (5\%) yaitu sebesar 0,0078 untuk variabel profitabilitas dan 0, 0045 untuk variabel likuiditas. Sedangkan variabel pertumbuhan perusahaan tidak berpengaruh secara parsial terhadap nilai perusahaan dengan nilai $\mathrm{P}$ yang diperoleh sebesar 0, 6908 lebih besar dari pada nilai signifikansi (5\%) yang digunakan dalam penelitian ini. Hasil Uji t model regresi penelitian dirangkum melalui tabel berikut:

\section{Tabel 9}

\section{Hasil Uji t}

\begin{tabular}{|c|c|c|c|}
\hline Variabel & Nilai $_{\text {hitung }}$ & $\mathbf{P}$ & Hasil \\
\hline ROE & 2.6908 & .0078 & Signifikan \\
\hline TAG & .4221 & .6734 & Tidak Signifikan \\
\hline Current Ratio & -2.8733 & .0045 & Signifikan \\
\hline
\end{tabular}

Sumber : Data diolah penulis menggunakan SPSS 24, 2020

\section{Pembahasan}

\section{Pengaruh Profitabilitas terhadap nilai perusahaan}

Hasil uji t dalam penelitian ini menunjukkan bahwa profitabilitas berpengaruh secara parsial terhadap nilai perusahaan dengan nilai $\mathrm{P}$ yang diperoleh pada tabel 8 yaitu sebesar 0,0078 lebih kecil dari nilai signifikansi (5\%) yang digunakan dalam penelitian ini. Pada tabel 8 juga menunjukkan bahwa $t_{\text {hitung }}$ yang diperoleh variabel profitabilitas sebesar 2,6908 yang menunjukkan bahwa arah koefisien dari variabel profitabilitas adalah positif. Dari hasil tersebut dapat disimpulkan bahwa profitabilitas berpengaruh positif signifikan terhadap nilai perusahaan. Hal itu juga mengartikan bahwa hipotesis pertama dalam penelitian ini diterima. Hasil tersebut sejalan dengan penelitian yang dilakukan oleh Arindita dan Sampurno (2015) menjelaskan bahwa profitabilitas berpengaruh positif signifikan terhadap nilai perusahaan. Semakin meningkatnya profitabilitas suatu perusahaan maka akan meningkatkan pula nilai perusahaannya karena dengan meningkatnya profitabilitas menunjukkan bahwa kinerja perusahaan meningkat dan dapat diperkirakan bahwa prospek kedepannya perusahaan baik 
sehingga mampu menarik investor dan meningkatkan harga saham perusahaan yang mana akan mencerminkan meningkatnya pula nilai perusahaan.

\section{Pengaruh Pertumbuhan Perusahaan terhadap nilai perusahaan}

Hasil uji $\mathrm{t}$ dalam penelitian ini menunjukkan bahwa pertumbuhan perusahaan tidak berpengaruh secara parsial terhadap nilai perusahaan dengan nilai $\mathrm{P}$ yang diperoleh pada tabel 8 yaitu sebesar 0,6734 lebih besar dari nilai signifikansi (5\%) yang digunakan dalam penelitian ini. Pada tabel 8 juga menunjukkan bahwa thitung yang diperoleh variabel pertumbuhan perusahaan sebesar 0,4221 yang menunjukkan bahwa arah koefisien dari variabel profitabilitas adalah positif. Dari hasil tersebut dapat disimpulkan bahwa pertumbuhan perusahaan tidak berpengaruh terhadap nilai perusahaan. Hal itu juga mengartikan bahwa hipotesis kedua dalam penelitian ini ditolak. Hal itu sejalan dengan penelitian yang dilakukan Dewi dan Candradewi (2018) yang menyatakan bahwa pertumbuhan perusahaan tidak berpengaruh terhadap nilai perusahaan. Tidak adanya pengaruh tersebut menunjukkan bahwa apabila pertumbuhan perusahaan meningkat maka nilai perusahaan tidak akan mengalami peningkatan. Hal tersebut terjadi karena jika pertumbuhan perusahaan tinggi maka dana yang dibutuhkan untuk kegiatan operasional perusahaan juga tinggi. Saat perusahaan fokus pada pertumbuhan perusahaan maka perusahaan akan menggunakan seluruh dananya untuk membiayai pertumbuhan perusahaan tersebut dan tidak memperhatikan kesejahteraan pemegang sahamnya.

\section{Pengaruh Likuiditas terhadap nilai perusahaan}

Hasil uji t dalam penelitian ini menunjukkan bahwa Likuiditas berpengaruh secara parsial terhadap nilai perusahaan dengan nilai $\mathrm{P}$ yang diperoleh yaitu sebesar 0,0045 lebih kecil dari nilai signifikansi (5\%) yang digunakan dalam penelitian ini. Pada tabel 8 juga menunjukkan bahwa thitung yang diperoleh variabel likuiditas sebesar 2,8733 yang menunjukkan bahwa arah koefisien dari variabel likuiditas adalah negatif. Dari hasil tersebut dapat disimpulkan bahwa likuiditas berpengaruh negatif signifikan terhadap nilai perusahaan. Hal itu juga mengartikan bahwa hipotesis ketiga dalam penelitian ini ditolak. Hasil tersebut sejalan dengan penelitian yang dilakukan oleh Permana dan Rahyuda (2019) yang menyatakan bahwa likuiditas berpengaruh negatif signifikan terhadap nilai perusahaan. Keputusan perusahaan untuk membayar kewajiban yang tinggi (Tingkat Likuidasi yang terlalu tinggi) akan mempengaruhi tingkat 
pengembalian kepada pemegang saham. Hal itu disebabkan karena Likuiditas yang terlalu tinggi juga dapat menghambat kemampuan perusahaan dalam menghasilkan laba dikarenakan banyaknya kas yang menganggur sehingga menurunkan produktivitas perusahaan dalam menghasilkan laba. Laba yang kecil akan mencerminkan tingkat pengembalian yang kecil pula sehingga akan membuat para investor mempertimbangkan kembali keputusannya dalam melakukan investasi yang pada akhirnya akan mempengaruhi nilai perusahaan.

\section{SIMPULAN DAN REKOMENDASI}

Kesimpulan pada penelitian ini adalah variabel profitabilitas memiliki pengaruh yang positif dan signifikan terhadap nilai perusahaan di perusahaan sektor industri barang konsumsi yang terdaftar di Bursa Efek Indonesia tahun 2014 - 2018. Pengaruh positif dan signifikan tersebut menunjukkan semakin meningkatnya profitabilitas suatu perusahaan maka akan meningkatkan pula nilai perusahaannya. Variabel pertumbuhan perusahaan tidak memiliki pengaruh terhadap nilai perusahaan di perusahaan sektor industri barang konsumsi yang terdaftar di Bursa Efek Indonesia tahun 2014 - 2018. Hasil penelitian tersebut menunjukkan bahwa meningkat atau menurunnya pertumbuhan perusahaan tidak berpengaruh terhadap nilai perusahaan. Dan variabel likuiditas memiliki pengaruh yang negatif dan signifikan terhadap nilai perusahaan di perusahaan sektor industri barang konsumsi yang terdaftar di Bursa Efek Indonesia tahun 2014 - 2018. Pengaruh negatif dan signifikan tersebut menunjukkan bahwa tingginya likuiditas perusahaan tidak selalu dapat meningkatkan nilai perusahaan.

\section{DAFTAR PUSTAKA}

Arifianto, M., \& Chabachid, M. (2016). Analisis Faktor-Faktor Yang Mempengaruhi Nilai Perusahaan ( Studi Kasus Pada Perusahaan Yang Terdaftar Pada Indeks Lq-45 Periode 2011-2014). Diponegoro Journal Of Management, 5(1), 1-12. Https://Doi.Org/Http://Ejournal-S1.Undip.Ac.Id/Index.Php/Dbr

Arindita, G., Sampurno, R. D. (2015). Analisis Pengaruh Struktur Modal, Profitabilitas, Kebijakan Dividen, Dan Size Terhadap Nilai Perusahaan (Studi Kasus Pada Perusahaan Wholesale Dan Retail Yang Terdaftar Di Bei Tahun 2008-2012). Diponegoro Journal Of Management, Volume 4,(Issn (Online): 2337-3792.), Hal. 1-11.

Astuti, N. K. B., \& Yadnya, I. P. (2019). Pengaruh Profitabilitas, Likuiditas, Dan Ukuran Perusahaan Terhadap Nilai Perusahaan Melalui Kebijakan Dividen. Jurnal Manajemen Udayana, 8(5), 3275-3302.

Brigham, E. F., \& Houston, J. F. (2018). Dasar-Dasar Manajemen Keuangan (14th Ed.). Jakarta: Salemba Empat. 
Cahyani, G. A. P., \& Wirawati, N. G. P. (2019). Pengaruh Likuiditas, Kebijakan Dividen, Profitabilitas, Dan Ukuran Perusahaan Pada Nilai Perusahaan. E-Jurnal Akuntansi, 27, 1263. Https://Doi.Org/10.24843/Eja.2019.V27.I02.P16

Dewi, D. A. I. Y. M., \& Sudiartha, G. M. (2017). Pengaruh Profitabilitas, Ukuran Perusahaan, Dan Pertumbuhan Aset Terhadap Struktur Modal Dan Nilai Perusahaan. Jurnal Manajemen Udayana, 6(4), 2222-2252.

Dewi, D., \& Sudiartha, G. (2017). Pengaruh Profitabilitas, Ukuran Perusahaan, Dan Pertumbuhan Aset Terhadap Struktur Modal Dan Nilai Perusahaan. E-Jurnal Manajemen Universitas Udayana, 6(4), 2222-2252.

Dewi, M. A. P., \& Candradewi, M. R. (2018). Pengaruh Pertumbuhan Perusahaan Dan Profitabilitas Terhadap Struktur Modal Dan Nilai Perusahaan. Jurnal Manajemen Udayana, 7(8), 4385-4416.

Ghozali, I. (2016). Aplikasi Analisis Multivariate Dengan Program Ibm Spss 23 (8th Ed.). Semarang: Badan Penerbit Universitas Diponegoro. Https://Doi.Org/10.2307/1579941

Hasbi, H. (2015). Islamic Microfinance Institution: The Capital Structure, Growth, Performance And Value Of Firm In Indonesia. Procedia - Social And Behavioral Sciences, 211, 1073-1080. Https://Doi.Org/10.1016/J.Sbspro.2015.11.143

Herawati, T. (2011). Pengaruh Kebijakan Dividen, Kebijakan Hutang Dan Profitabilitas Terhadap Nilai Perusahaan. 1-18.

Husnan, S., \& Pudjiastuti, E. (2015). Dasar-Dasar Manajemen Keuangan. Yogyakarta: Upp Stim Ykpn.

I Putu Sukarya, \& Baskara, I. G. K. (2019). Pengaruh Profitabilitas, Leverage, Dan Likuiditas Terhadap Nilai Perusahaan Sub Sektor Food And Beverages. E-Jurnal Manajemen, $8(1)$, 7399-7428. Https://Doi.Org/Https://Doi.Org/10.24843/Ejmunud.2019.V8.I1.P16

Juhandi, N., Sudarma, M., Aisjah, S., \& Rofiaty. (2013). The Effects Of Internal Factors And Stock Ownership Structure On Dividend Policy On Company's Value A Study On Manufacturing Companies Listed On The Indonesia Stock Exchange (Idx). International Journal Of Business And Management Invention, 2(11), 6-18. Https://Doi.Org/10.1098/Rsta.2009.0153

Kurniawan, N., \& Mawardi, W. (2017). Analisis Pengaruh Profitabilitas Keputusan Investasi Keputusan Pendanaan Dan Kebijakan Dividen Terhadap Nilai Perusahaan (Studi Pada Perusahaan Yang Terdaftar Di Jakarta Islamic Index Tahun 20112015). Diponegoro Journal Of Management, 6(2), 1-11. Https://Doi.Org/Http://Ejournal-S1.Undip.Ac.Id/Index.Php/Dbr

Levine, D. M., Stephan, D. F., \& Szabat, K. (2017). Statistic For Manager Using Microsoft Excel. England: Pearson Edutical Limited.

Noviani, A. V., Atahau, A. D. R., \& Robiyanto, R. (2019). Struktur Modal, Profitabilitas, Dan Nilai Perusahaan: Efek Moderasi Good Corporate Governance. Jurnal Ekonomi Dan Bisnis, 22(2), 391-415. Https://Doi.Org/10.24914/Jeb.V22i2.2601

Parta, K. A. C. P. P., \& Sedana, I. B. P. (2018). Peran Struktur Modal Dalam Memediasi Pengaruh Pada Perusahaan Properti Di Bei. 7(5), 2680-2709. 
Https://Doi.Org/Bagus, I., \& Sedana, P. (2018). Peran Struktur Modal Dalam Memediasi Pengaruh Pada Perusahaan Properti Di Bei Kadek Ayu Citra Pradnya Paramita Parta 1 Fakultas Ekonomi Dan Bisnis Universitas Udayana , Bali , Indonesia Pertumbuhan Ekonomi Indonesia Saat Ini Semakin Meningkat, Sehingga Menyebabkan Terjadinya Peningkatan Persaingan Bisnis Oleh Berbagai Perusahaan. Persaingan Bisnis Tersebut Menyebabkan Berbagai Perusahaan Berusaha Untuk Melakukan Berbagai Upaya Untuk Dapat Meningkatkan Nilai Peru

Permana, A. A. N. B. A., \& Rahyuda, H. (2018). Pengaruh Profitabilitas, Solvabilitas,Likuiditas, Dan Inflasi Terhadap Nilai Perusahaan. E-Jurnal Manajemen Universitas Udayana, 8(3), 1577-1607. Https://Doi.Org/10.24843/Ejmunud.2019.V08.I03.P15

Rajagukguk, L., Ariesta, V., \& Pakpahan, Y. (2019). Analisis Pengaruh Profitabilitas, Ukuran Perusahaan, Keputusan Investasi, Dan Kebijakan Utang Terhadap Nilai Perusahaan. Jurnal Inspirasi Bisnis Dan Manajemen, 3(1), 77. Https://Doi.Org/10.33603/Jibm.V3i1.2079

Sekaran, U., \& Bougie, R. (2017). Metode Penelitian Untuk Bisnis. Jakarta: Salemba Empat.

Sudana, I. M. (2011). Manajemen Keuangan Perusahaan Teori \& Praktik. In Erlangga. Https://Doi.Org/10.1145/2505515.2507827

Sukamulja, S. (2019). Analisis Laporan Keuangan Sebagai Dasar Pengambilan Keputusan Investasi (F. M (Ed.)). Penerbit Andi.

Suwardika, I. N. A., \& Mustanda, I. K. (2017). Pengaruh Leverage, Ukuran Perusahaan, Pertumbuhan Perusahaan, Dan Profitabilitas Terhadap Nilai Perusahaan Pada Perusahaan Properti. Jurnal Manajemen Udayana, 6(3), 1248-1277.

Thomas, P. (2011). Dasar-Dasar Keuangan. Semarang: Unnes Press.

Uttari, I. A. S., \& Yadnya, I. P. (2018). Kebijakan Dividen Dan Nilai Perusahaan ( Studi Pada Perusahaan Manufaktur Yang Terdaftar Di Bursa Efek Indonesia ). E-Jurnal Manajemen Unud, 7(6), 2942-2970. Https://Doi.Org/Https://Doi.Org/10.24843/Ejmunud.2018.V7.I06.P4

Yunita, I. G. P. A. O., \& Artini, L. G. S. (2019). Peran Struktur Modal Sebagai Mediator Antara Pertumbuhan Perusahaan Dan Nilai Perusahaaan. E-Jurnal Manajemen, 8(12), 7013-7032. 